\title{
An evaluation of language philosophy of Yunus Emre and Mevlana
}

\author{
Esra Karabacak $^{1, *}$, and Asll Piro $^{2}$ \\ ${ }^{1}$ Near East University, Faculty of Arts and Sciences, Turkish Language and Literature, Nicosia- \\ 99138, North Cyprus \\ ${ }^{2}$ Near East University, Faculty of Arts and Sciences, Turkish Language and Literature, Nicosia- \\ 99138, North Cyprus
}

\begin{abstract}
Philosophers express, share with other people and convey them their opinions through language. We can define language as a system of symbols which is used for expressing any mental activity and its transfer from one mind to another. Language plays an essential role in the spreading and sharing of philosophy. Language is an essential tool of communication for conveying opinions. As Mevlana stated, "no matter how much you know, what you say is not more than what others understand." Mevlana's poems, his poetry and the meanings he added to statements and words are very important for literature and its history. What is the place of literary works in language philosophy in Turkish literature? This is worth examining. Words have gained new meanings and their meanings extended to abstractions as a result of certain developments in the poetry tradition in the East. Likewise, the philosophical dimension of language can be solved based on the works of poets and authors who are considered as close to each other. Yunus Emre emphasized the supremacy of meaning and valuelessness of material things which integrated carrying the load of Islamic Sufism. Scientists who study Yunus Emre claim that he widely read and internalized the poems of poets who came before him. In addition to the general style characteristics of the poet, he also has some peculiar features. Choosing examples from the poems of Mevlana and Yunus Emre, evaluations will be made in terms of language and philosophy which will explore similar characteristics.
\end{abstract}

\section{Introduction}

Human mind has the ability of creating concepts through abstractions. Human beings want to create some propositions from these concepts and express what they want to tell. Language is a system of symbols which is used for expressing any mental activity and its transfer from one mind to another. Abstract thinking power provided by language is the most important factor in conceptualization of the reality of people outside themselves and establishment of relations with the community. It is through language that we can perceive

\footnotetext{
*Corresponding author: esra.karabacak@neu.edu.tr
} 
reality. We are able to produce knowledge about values through language. Language has an essential role in the spreading and sharing of philosophy. Language is an essential means of communication. The interaction between minds is only possible through language. Language is the means of conveying opinions. In Mevlana's words, "no matter how much you know, what you say is not more than what others understand" [1].

The literary aspect of Mevlana and his poet personality is essential in terms of meanings that he added to words. That words gain new meanings and the expression extends from concrete to abstract is the result of certain developments in the poetry tradition in the East. The differentiation in style in Persian poetry in Seljukian period and theme preferences is explained as Seljukian Style. In this period poet personality also went through differentiation. Mevlana was an exception to classical court poet personality and affected the direction of poetry. Mevlana and his son Sultan Veled claimed that meaning had supremacy and material things were valueless. The path of creating new and different meanings with old words was approved and reinforced by Mevlana who considerably benefited from literary tradition. Mevlana's poetry bears general style characteristics of Persian poetry as well as some unique features.

Language philosophy is a part belonging to human beings, a branch of philosophy which deals with unique problems just like history philosophy. Language philosophy does not examine the mutual relations between elements which form a language; it examines the relations between them and the world. Language can serve as a means of communication only through this type of relationships. Language philosophy tries to explain how language works, how it can be useful and how it is used for communication. How and according to which rules is the function of indicating these beings performed? Several approaches on Mevlana are very meaningful; but the topic of language must also be examined. Yet, his philosophical opinions, socio-cultural viewpoints and didactic-educating dimensions are also remarkable in addition to his literary personality [2].

As a result, according to Mevlana the peace among opposites on earth tells that it is the most important and inevitable reality for the creatures so that they can live their lives. Certainly the side effects that controversies will create must not be forgotten. He believed that contrasts make the universe dynamic in a harmonious order and ensure the movement among themselves and progress. Besides, by explaining this reality, he even watches negative events with tolerance and tries to explain the contrasts among them as the reflection of peace. Mevlana explains the following reality: "in the universe of the one and godhead, there is no problem of contrast any more. There is equality and sameness. Every object, event etc. that we think as contrasting are actions that will take us to greatness. Accepting this action is peace itself!" [3].

I am silence, thought, language and voice

I am the sound of ney.

With these words, Mevlana asks the question of how is the language processed and woven? What is the opinion-based impact on language? This can be solved by examining his general philosophy and then its reflection on language.

\section{Examination}

Wisdom in Mevlana's thought, which is reflected on language, is expressed in concrete terms instead of abstract terms. He follows the topic of wisdom in the society. In this context, he does not reprimand the contrasts and classifications among people and thinks that mutual cooperation and convergence among people is a peace factor based on "the principle of integration". With this opinion, it is possible to accept the "peace in contrast" of Mevlana as an intellectual way of thinking. 
As is known, there are three pre-eminent personalities in Mevlana. This means that there is vertical personality instead of horizontal personality. In other words, his personality in the field of science and wisdom has three stages; it gains meaning with Crudity, Maturity and Burning. He defines life as a process and explains that it gains meaning not with horizontal movement but with vertical movement towards greatness. In the crude (raw) period everything must be tolerated, as all events are caused by lack of knowledge and education; however, in maturity period everything finds its place and then gains meaning from Beka-Billah (Reaching the endless life in the existence of God) to fenafillah (Perishing in the existence of God). Contrast is caused by crudity, whereas consensus and peace is caused by maturity. As a result, burning with the love of God is gaining meaning in Him. Mevlana explains the maturity of human beings in this regard and states that peace can be ensured only in this direction. He inherited the regular meaning search concerning peace from his father, Burhaneddin Muhakkik-i Termezî, and Şems-i Tebrizî [4].

The subject or theme in the focus of language philosophy is meaning and its nature. The topic of meaning is an essential point where all researches in language philosophy intersect. The question in language philosophy is not like what does this word mean? The question is more like what does it mean when something tells another thing? This question can also be asked as what does it mean when a part in a language system tells something outside that language system? The elements belonging to language are words, meaning names, noun phrases, adjectives, conjunctions, adverbs, prepositions etc., simple-complicated sentences, written texts or cliché expressions. Concepts which indicate all kinds of beings including abstract, concrete, material or spiritual are extremely essential while examining a literary type.

It is clear that Mevlana is knowledgeable about Greek philosophy. He mentions Plato, Calinus and sophists in Mesnevi. His closeness to philosophy is also reflected on his usage of language. He also includes the opinions of Gazali and Avicenna in his works who examined Greek philosophy. Therefore, with the impact of this philosophy he moves words in word groups around a main center while using language. He thinks that every word is the cornerstone of poetry. Every word has a different meaning. However, in poetry and especially in lyric and pastoral poetry moving words just like the notes in music is the effect of a part of philosophy.

I am both me and you not only in me but also in you,

I am both mine and yours, and you are mine,

So weird have I become that

I do not know if you are me, or I am you.

Mevlana criticized the thinkers who accept mind as basis. He cites the friendship of a Bedouin and a philosopher on the road: the Bedouin loaded two full bags on his camel. One bag had wheat and the other had sand. The philosopher warned the Bedouin that he should pour sand and divide the wheat into two bags in equal amounts so that the load would be lighter. The Bedouin adored this opinion and became the zealot of the philosopher. In the end, the Bedouin understood that the philosopher is a penniless and troublesome person and moved away from him. He said words meaning your intelligence and wisdom is useless and broke with the philosopher. Mevlana mostly defines thinkers deprived of faith by the word "philosopher". He ended his story as following: the wisdom based on nature and consisting of imagination is a wisdom deprived of the inspiration of the light of God. Using the words philosopher, Bedouin, imagination and wisdom here actually shows that he chose complementary elements in terms of meaning. Certainly the words used in a narrative constitute the internal part of the expression; this means that it is the main element. Mevlana is one of the authors and poems who use narrative expression best. Especially in his poems the effect of narrative can be witnessed [5]. 
Next thing you know they deceive me with gold,

Next thing you know they deceive me with fame and honor.

However I did not want gold or anything from him,

And it has been a long time since I ignored fame and honor.

I am an iron,

Running from magnet.

I am a straw,

Which sidestepped to magnets.

Language philosophy examines and compares expression patterns, determines the strengths and weaknesses in the form of a theory and tries to implement a more ideal meaning theory. It is important to determine the manner with which the author employs language for customized uses. What we obtain by looking at the vocabulary is not the meaning of word, but the definition of a word by a series of other words.

I am an iron, running from magnet.

I am a straw, which sidestepped to magnets.

I am such a particle that I revolted against entire worlds.

I revolted against the air and soil, fire and water.

Water, fire, air and soil, which were frequently used in ancient philosophy, are among impressive elements in Mevlana. In the verses given above, iron, magnet, particle, straw, fire, water, air and soil are used in a philosophical order related to the word revolt. In the end, it is finalized with an expression which is opposite to but supportive of "revolt". And the movement was based on freedom of opinion.

Since ancient times, thinkers have been asking themselves how beings came to existence. Some Greek thinkers claimed that the first element of existence was water, air, fire or soil. In Islam, the emphasis is on that the existence came into being with the will of God. Those who adopted midway in Islam believe that beings are created with the words kün feyekün, meaning "comes into existence when He says "be". However, there are different comments in Islam related to existence. Mevlana tried to express the unity of beings. In essence, the unity in existence philosophy was deducted from the hadiths of Muhammed the Prophet on the topic.

While Mevlana explains responsibility, which is one of the most important elements in human life, the processing of language is essential: a man entered into a vineyard, shook the apricot tree and began to eat the fruits. The owner of the vineyard saw him and said: "Are you not afraid of God?" The man answered: "Why should I be? The tree is God's tree, I am God's subject, and God's subject is eating God's property." The owner of the vineyard tied him to a tree and began to beat the hell out of him with a stick. The man could not stand the pain of the stick and asked the owner: "Are you not afraid of God?" The owner answered: "Why should I be? You are God's subject, this is God's stick, I am beating God's subject". Thus Mevlana explained that the man was responsible for the act of stealing.

The wisdom in Mevlana's thought is explained not in abstract but in concrete terms. He follows the topic of wisdom in the society. In this context, he does not reprimand the contrasts and classifications among people and thinks that mutual cooperation and convergence among people is a peace factor based on "the principle of integration". With this opinion, it is possible to accept the "peace in contrast" of Mevlana as an intellectual way of thinking [6].

Mevlana gave a superior value to human beings and saw them as beings that deserve the love of God. He sought everything in humans. He thought that as a human being becomes more refined in terms of spirituality, he comprehends that everything is just a dream, and 
that only God exists as being. According to Mevlana, He is the one who constitutes chemistry. What is chemistry after all? One has to vanish vis-à-vis his existence. What is existence in his presence? It is just a meaningless thing. The failure to know that this existence can come into being only with the existence of God is the evidence of blindness. Such expressions of belief display the connection of opinion-based language philosophy with human philosophy in the clearest and most beautiful manner.

Mevlana's explanation of death is also very critical in terms of language. Death is inevitable for human life. It is putting a full-stop to the life in this world. Mevlana is not afraid of death and he almost tries to endear death to people. According to his philosophy, human beings are in this universe because God wished so. Human beings are part of the existence. He thinks that a lover does not fear from reaching his beloved one. This is what death is like. It is being elevated to the level of God. Here opposite words express an entirety. However, exactly the opposite was expected. Complementary expressions give the wording more strength.

He always states that reality and things cannot be comprehended with the mind. By doing this, he moves words and criticizes the disarrangement of the mind. A deep system can be noticed in his works. He claims that a disorganized mind is illuminated with light. A deep system can be noticed in his works. The words are ordered according to this system. Even interacted concepts are presented in a more understandable method and style. Mevlana believes that it is material and form which interests mind. Similar to Islamic philosophers, Mevlana accepts some Aristotelean opinions and supports them with words. He intertwines concepts which are among the most important elements of language philosophy [7].

Do you think that I can recruit a rose if I saw a thorn? If you do not saw one, no sapling gives you a rose. Streams are just like wheat and the world is like a windmill; if you take adobe to the windmill all you obtain is soil.

Here the word rose connects sentences with different meanings. The usage of repetitions is one of the most important elements of language features. The analogy between world and windmill is important as an example of emulating art in prose.

A human being is an eye; beyond him there is nothing more than skin and meat. The value of human is equal to what his eyes see. Here "eye" accommodates several meanings; what matters is just what a person sees. What they see are put into words within a system of thought during when the relation between language and philosophy emerges and completes each other.

"Heart, word and love will blend in poetry; and illuminate hearts without love". With these expressions, he emphasized that internal structure and external features can be expressed with poetry. Emotions are fed in poetry and cast into words.

My friend, I am you and you are me.

Come here, come closer...

It is that you are me and I am you,

Then what is that you and me for?

Here language moves through personal pronouns. Expressions are based on pronouns.

The meaning is reinforced with repetition group and duplexing with pronouns. Certainly while assigning this task to meaning, the relation between language and opinion is completed. As can be seen, his poems are easily understandable for all cultures and the entire humanity. The words he uses belong to the common language which can be generally understood by everyone.

Did not I tell you not to go there?

Did not I tell you that only I could know you?

Did not I tell you I am the fountain of life in this country of absence?

Even if you become angry and desert me, 
Even if you go to a distance of one hundred thousand years, did I not tell you that I am what you will come back and reach?

A general opinion is conveyed with the question expressions above. Conditional sentences completed these expressions. The repetition of "did I not tell you" turns negativity into positivity. Although it is a small element, it conveys an important way of thinking into language [8].

One of the most beautiful and meaningful verses;

Be like the sun in compassion and mercy,

Be like the night in covering the mistakes of others,

Be like a river in goodness and generosity,

Be like a dead in anger and quick temper,

Be like soil in humility and modesty,

Be like a sea in tolerance,

Either seem as you are or be as you seem...

are the fundamental philosophy of life. And these opinions are reflected to the words only in a certain unity of emotions. By using analogies and different words with the same meaning, emphasis has been put on how human beings would be in life. Mevlana almost became the language of all creatures.

\section{As for Yunus Emre...}

When Yunus is mentioned, Anatolia comes to mind. His poems are unadorned, far from vanity and highly sincere. Anatolian people found themselves in the poems of Yunus. According to Yunus Emre, a person must first know the language of his society, and speak that language. Yunus Emre was a man of the people and he used folk language. His expressions in his poems are very clear and plain.

The language of Yunus Emre is Old Oghuz Turkish. The century when Yunus lived iswas a transition period for the history of Turkish language. On one side there were the traces of old Turkish; on the other side there were the traces of newly shaped Old Anatolian Turkish; both of them can be found in the poems of Yunus. In other words, almost all of the poets in this period have similar characteristics. Yunus Emre used several words which have the traces of Old Turkish [9].

My life, you are deceiving me

Oh, my life, what shall I do with you?

You made me unable to move

Oh, my life, what shall I do with you?

All I had was you

You were soul in my soul

You were sultan to me

Oh, my life, what shall I do with you?

Even someone who knows a lot needs suggestion

He who wants to reach the destination should appear in sorrow

This road is evil distant the world is a trap for it

Those who fall in this trap should repel their guides

It is not easy to find any poems similar to his plain but beautiful poems which were written without concern for art. The hardly pronounceable opinions and excitements of Islamic Sufism can be seen instantly in his poems. Yunus Emre approved and reinforced the way of creating new and different meanings with old words and literary tradition was 
utilized considerably. As he was very close to philosophy, Yunus Emre used language as a philosophical element and brought a soft comment to his writings in every topic and even added an interpretation full of love to Islam religion and contributed to the spreading of love for human beings, solidarity and sincere love for religion. Language philosophy examines and compares patterns of expressions, determines their strong and weak points in the form of a theory and, as a result, tries to apply a more ideal theory of meaning [10].

Poems of Yunus Emre express the feelings, enthusiasm, longings and dreams of human beings in a unique language. It makes language more vivid, beautiful and effective and adds it a personality. Poet chose the words in daily language with care. He added them brand new meanings. He added new values and meanings to the used language. He included analogies and metaphors. He turned concrete beings into abstract beings and vice versa. As a result, he added a depth of meaning to feelings and opinions. Art was utilized in order to avoid monotony in the poems:

Your love took me from myself

I need you and only you

I burn yesterday and today

I need you and only you

I am not happy with wealth

I am not sad with poverty

Diverting myself with your love

I need you and only you

The poet expressed his feelings, opinions and dreams with sentences. Daily speaking language and poetry language are different from each other. Poet chose the words in daily language with care and added them brand new meanings. He madeuse of dreams, images and impression while explaining them. He also utilized some analogies and metaphors in addition to the form, rhyme, measure, harmony, emphasis and toning of the poem while using words. He turned concrete beings into abstract beings and vice versa. As a result, he added a depth of meaning to feelings and opinions. Some figures of speech are used in order to increase the power of word in poems. Figures of speech add depth to the meaning and elegance to feelings in poetry.

If the poem is not only a sum of the words that constitute it but is well beyond this compilation with some divine characteristic, the viewpoint of the poet towards life and his stance can be explained better:

Falls upon mountain and makes it ash,

Falls upon hearts and makes a road,

Turns sultans into slaves,

Love is an erudite object.

Whom did the arrow touch?

There is no resent and anxiety.

Ferhad and his sighs are high,

Love is an object of absence.

\section{Conclusion}

Yunus Emre and Mevlana are among the writers who make best use of language. They explained the topic of unity especially in the enthusiasm of love for God and brought vividness to Islamic Sufism. While using language, human philosophy was emphasized. Language gave life a meaning, and it was given a prominent place while evaluating the place of human in universe. While creating a symbol in poetry, comparisons, exaggerations, and metaphors are used. Human mind has the ability of creating concepts by abstraction. 
People create propositions from these concepts and try to express their intentions. From this perspective, especially poetry language is easily shared with other people and transferred to them. Yunus Emre added new meanings to words in addition to their lexical meaning and took them out of the sentence structure within the general rules of language and created different compositions of words. The power of abstract thinking provided by Yunus Emre's poems have become the most important factor in the conceptualization of reality by people and their ability to establish relations with their environment.

Mevlana is one of the writers who make best use of the relation between language and opinion. He especially explained the topic of unity in the enthusiasm of love for God and brought vividness to Islamic Sufism. While using language, human philosophy was emphasized. Language gave life a meaning, and it was given a prominent place while evaluating the place of human in universe. He acted as the pioneer of narrative expression. However, we understand from the foregoing that language, religion, philosophy, sociology, history and literature are all intertwined, or rather, complete each other. Mevlana's words have a wide prominence in several world languages in folk poems and mystic philosophy.

Mevlana's Dewan and Mesnevi are translated in several languages. His works are affected by both Eastern and Western thought. He is a major Turkish thinker. Although more than seven centuries passed, his philosophy is still being read and adopted by people. It is beyond doubt that Mevlana has an important place in Islamic philosophy. In addition, he played an essential role in literature in his use of language and expression techniques. Mevlana gave huge importance to the freedom of conscious. He brought a soft interpretation to the Islam religion. In ethical terms, he recommended behaviors which would end with happiness. He gave importance to good intentions and the power of will. In all these expressions, he brought language to the fore. These philosophical opinions have become the most beautiful examples of language philosophy.

The examination which began with the following words:

I am silence, thought, language and voice.

I am the sound of ney.

emphasises that the operation of language in Mevlana is intertwined with word patterns, and opinion-based impact in language. It is possible that Mevlana is a good beginning and an important example in terms of language philosophy. It will be suitable to complete with an important saying of Mevlana. Do not look for our grave on the ground after we die. Our grave is in the hearts of the wise... And when we enter the hearts, we enter language.

\section{References}

1. D. Aksan, Semantics and Turkish semantics, (Ankara University Faculty of Language and History-Geography Publications, Ankara, 1978)

2. Z. Özcan, Language Philosophy I-II, (Sentez Publications, Ankara, 2014)

3. Gölpınarl, Mevlana Celâleddin, (İnkılap Publications, Ankara 1999)

4. G. Golkarian, Mevlana and His Philosophy. Sohan Journal, 6/3 (2014)

5. M. Tatc1, Yunus Emre Dewan-text with Criticism-II, (Ministry of Culture Publications, Ankara, 1990)

6. G. Golkarian, Peace and Consensus Understanding in Mevlana's Views, Doğu Esintileri (Eastern Breeze), 4, (2017)

7. S. Eyüboğlu, Yunus Emre (Cem Publications, İstanbul, 1971)

8. Kabakl1, Mevlana, (Toker Publications, İstanbul, 1972)

9. E. J. W. Gibb, History of Ottoman Poetry. Translated by Ali Çavuşoğlu, (Akçăg Publications, Ankara, 1999)

10. A. Kemal, Yunus Emre, (Parıltı Publications, İstanbul, 2004). 